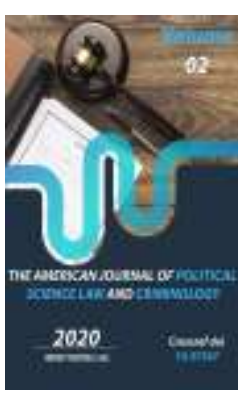

\title{
Processes Of Forming New Centers Of Power In The SCO Space
}

Journal Website: http://usajournalshub.c om/index,php/tajpslc

Copyright: Original content from this work may be used under the terms of the creative commons attributes 4.0 licence.

\author{
Mukhtor Nazirov \\ PhD In Political Sciences, International Islamic Academy Of Uzbekistan A.Kadiri, Tashkent, \\ Uzbekistan
}

\section{ABSTRACT}

This article studies some aspects of the current condition of world order, as well as conceptually sets out thoughts on the trend of the emergence of new centers of power in Asia. In particular, the essence of the processes of convergence of integration associations such as "One Belt, One Road" and the EAEU, and the prospects of creating a "Greater Eurasian Partnership" in the SCO space are analyzed.

\section{KEYWORDS}

Globalization; world order; SCO; EAEU; Road and Belt; Central Asia; centers of power; geopolitics; USA; China; Russia; integration.

\section{INTRODUCTION}

If the period of the Cold War was characterized by the confrontation between the USSR and the United States, including in the nuclear sphere, then since 1991 the global world has entered a new phase of its development: the bipolar system generated by the Second World War has disappeared. The time has come for
NATO and the leading power of the world, the United States, to seriously unrestricted dominance in the world arena, which for a time succeeded in pushing not only its allies in the North Atlantic alliance, but also all other states to secondary roles in world politics. 
The United States initiated the formation of such a world order, which it saw primarily as liberal - based on the values of a market economy, the Western model of democracy and human rights. It is no secret that these same ideas in the early 1990 s were shared by many who hoped that the new world order would become more organized and the situation more peaceful.

The essence of the mood of that time in the West, which considered itself the winner in the Cold War, was the concept of the "end of history" formulated by the American political scientist F. Fukuyama. According to the concept, liberal democracy will take possession of "various regions and cultures around the world" and will reveal the "final path of the ideological evolution of mankind" and "the final form of government in human society" - the very "end of history." (Fukuyama, 1989: 3-18).

This reaction to the end of the bipolar model of international relations turned out to be erroneous, and on a global scale, the victory of Western values and the Western model of development did not happen. In a new era, when international political institutions (especially the UN), which functioned throughout the second half of the twentieth century, were seriously shaken, and a new framework for security architecture was never built, alternative models of the established world order were proposed.

Since 2001, the form of decision-making in world politics has been the idea of "unilateral global domination by the leading power in the world", claiming to become a new alternative model of global regulation and governance.

Attempts to organize the international political process on the basis of "unilateralism", which prevented the United States from managing all events in the world, encountered the realities of the "post-American world", according to F.Zakaria, where the dynamics of the polycentric system of international relations was increasing. (Zakaria, 1989).

But it was not formed as a classical multipolar model, but rather as a "world without poles", where alternative centers of influence grew up. (Haass, 2008: 44-56).

In such a multi-level, highly mobile international structure, the global problems that had come to the fore required new multilateral approaches - from developed and developing states, international institutions, and non-state actors. (Malysheva, 2012: 10).

\section{RESULTS}

In the context of deepening globalization, the contemporary world order system is undergoing serious transformations, the balance of power between its subjects is changing, and uncertainty in international relations is emerging.

In the situation of profound transformations in world politics and economics, the importance of forming a more equitable polycentric model of the world order that meets the interests of each and every state, which will be based on the norms of international law and the principles of mutual respect and consideration of each other's interests, mutually beneficial cooperation, refusal of confrontation and conflicts, equal and indivisible security.

President of the Republic of Uzbekistan Shavkat Mirziyoyev, in his speech at the plenary session of the 75th anniversary session of the UN General Assembly, outlined the approaches and initiatives of Uzbekistan on a number of acute and urgent issues of regional and global importance for the world community. 
In particular, the Uzbek leader stated: "It is clear to all of us that the socio-economic landscape of the post-pandemic world will be completely different.

We need to work on the basis of new approaches and close cooperation against common threats to security and sustainable development". (un.int, 2020)

\section{DISCUSSION}

The organization of the international system is weakening, and it is being replaced by an unstructured world order.

According to the forecast of the prominent American political scientist H.Kissinger, in the 21st century within the international system several regional orders will coexist with their own norms and driving forces. In conditions when a universal consensus is unattainable, the implementation of the concept of equal and indivisible security seems unrealistic, while the main task of the actors will be to prevent a large-scale war and the fragmentation of international relations to a degree of chaos. (Konovalova, 2018: 135)

With many interpretations of the world order, the most balanced is the division of the centers of power into four levels: The United States is at the head of the world hierarchy, followed by economically comparable China and the European Union, and the third and fourth levels are occupied, respectively, by regional leaders and countries with more limited influence on world processes.

In this classification, Russia is placed between the second and third levels. This means that in terms of its economic and technological potential, Russia is more likely to belong to the category of regional powers, but its nuclear status, its place as a permanent member of the UN Security Council and its desire to participate in solving global problems allow it to be ranked among the world powers. (Lavrov, 2016: 8-20)

As a result of the complication of the structure of international relations, a polycentric international system is being formed, at the same time new centers of influence are emerging, and a significant potential for world development is shifting to Asia.

Currently, Asia - as one of the most rapidly developing regions of the world - is among the leaders in terms of intra- and foreign trade turnover. The share of intraregional trade has long exceeded $50 \%$ of the total trade turnover and continues to grow, except for the crisis years, and this trend is typical for most regions of the world. (ADB Report, 2017)

Since the middle of the first decade of this century, new guidelines have emerged in Beijing's foreign policy. By this time, China had become a significant player in the global economy. And now he is targeting leadership in world politics. China does not seek political leadership to impose a communist model on the world. Its mission is to become equal to countries playing a key role in creating a new world order, and to demonstrate to the world its readiness to take responsibility for global development. The aspirations for leadership are based on the integration of China's economy into the world economy. (Mikheev, 2008).

In recent years, the Asian space has seen the emergence of major regional initiatives put forward by the leading countries of the continent. The administration of former US President Barack Obama was the first to try to formulate a strategy for the development of transport and logistics networks through Central Asia and Russia to Europe under the auspices of the Great Silk Road, putting forward the concept of the New Silk Road, 
which is tied mainly to meeting the needs of the international coalition in Afghanistan.

China has its own initiatives of this kind - aimed at unifying regional efforts in the field of infrastructure construction "One Belt, One Road", and Japan - in the form of the "Partnership in the field of creating quality infrastructure" initiated by Shinzo Abe's cabinet. In November 2017, on the sidelines of the East Asia Summit, the concept of a "Free and Secure Indo-Pacific Region" was put forward, which, apparently, may soon be filled with political and economic content. (Novikov, 2018: 83).

Such concepts, which have a huge geographical coverage, can be considered a phenomenon of international politics in recent times. It should be noted that the impending changes in the balance of power in Asia create additional opportunities for major players in the SCO space.

It is known that in June 2016, Russian President Vladimir Putin put forward the concept of the Greater Eurasian Partnership, within which the Russian leader called for the creation of a large association with the participation of China, India, Pakistan, Iran, the CIS countries and a number of other states, which connected to Asia and Europe.

At the same time, it was announced about joint Russian-Chinese plans "to give an official start to negotiations on the creation of a comprehensive trade and economic partnership in Eurasia with the participation of the states of the Eurasian Economic Union and China." (tass.ru, 2016).

By November 2017, the essence of the Eurasian partnership became clear. It was proposed to deepen regional economic integration on the basis of the Eurasian Economic Union (EAEU) and China's Belt and Road Initiative (OBOR).
The authors of the project emphasized its flexibility and openness for joining other participants. (Putin, 2017).

The initiative was given special weight by the support of China, the largest economy in Asia and one of the continent's leading political players. The creation of Greater Eurasia is important for China, including in terms of ensuring national security.

In the current conditions, when the United States has relied on containing and limiting the growing influence of the PRC, it is vital for official Beijing to create a friendly environment in the world. Although this political line of the United States may theoretically change over time, the political rivalry between the PRC and the United States at the global level will only grow.

According to Chinese experts, the main way to create the Eurasian partnership should be economic, not political integration. Therefore, it is believed that the Great Eurasian Partnership project can be easily docked with the Chinese OBOR project, since the initial setting of both projects exactly on economic interaction completely coincides. The main part of the integration process can be the conjugation of the EAEU and the BRI initiative. (Li Yonghui, 2018: 44-45).

In recent years, China and Russia have done a lot of work in this direction. In May 2018, China and the EAEU signed the "Agreement on Trade and Economic Cooperation between China and the Eurasian Economic Union" and thus achieved the first success in liberalizing mutual trade and investment. This was the first step towards the creation of a free trade zone between the PRC and the EAEU.

Some experts note that the main goal of Russia is to make the Chinese project "One Belt, One Road" a tool to strengthen and improve the 
EAEU, to prevent competition between these two projects, and in the future to put the resources of the Chinese initiative as the basis for the formation of the economic and political community of Greater Eurasia. (Bordachev, 2015).

Meanwhile, Xi Jinping's long-term project reflects the concept of China's geopolitical rise as a new, growing superpower. But at the same time, it is argued that it is not directed against the SCO and does not undermine the development interests of either the SCO or the EAEU.

Western experts are skeptical about the integration projects of Moscow and Beijing. In their view, these projects are different in nature: while OBOR seeks to connect China with regions such as Europe, the Middle East, South Asia through Central Asia, the EAEU is a political project designed to create a proRussian regional bloc in order to organize preferential treatment for the domestic market of this association. (Cooley, 2016: 9).

Obviously, progress in this direction is facing a number of challenges. For example,

- The Chinese OBOR project may turn from geo-economics into geopolitics;

- The modest economic base of the EAEU in comparison with China;

- The lack of interest of a number of the countries of association in moving towards deeper integration, etc.

Thus, the processes of convergence of the integration projects of the OBOR and the EAEU will inevitably "cause a change not only in geoeconomic, but also in geopolitical accents in Eurasia." (Luzyanin, 2019: 98-113).

At the same time, strengthening the international legitimacy of the OBOR and the EAEU is of great importance for China and Russia in the context of the continuing confrontation with the United States and its allies.

\section{CONCLUSION}

Sum up, the current world order is characterized by a shift in the "center of gravity" to Asia and a stable trend towards the formation of polycentricity.

In this sense, the rapprochement between the OBOR and the EAEU is of great importance for the leadership of China and Russia in their attempts to form a new integration structure with the possibility of embedding it in a new geopolitical center in the space of Eurasia.

However, in the long term, the initiatives of the OBOR and the EAEU should not become the subject of rivalry between Russia and China in Central Asia and a mechanism for promoting strategic interests and strengthening influence in the region.

Therefore, it is important that these projects develop on the basis of the principle of equality of the parties from the point of view of deepening mutually beneficial cooperation in the economic, transport, innovation and other spheres, as well as the implementation of current capabilities of states. This format can serve the regional development of Central Asia.

\section{REFERENCES}

1. Fukuyama, F. (1989). The End of History. The National Interest. Iss.16, 318.

2. Zakaria, F. (1989). The Post-American World. W.W. Norton \& Company, 292 p.

3. Haass, R. (2008). The Age of NonPolarity. What will Follow the U.S. Dominance? Foreign Affairs. Vol. 87. Iss. 3, 44-56. 
4. Malysheva, D.B. (2012). Modern world politics in the context of the formation of a multipolar world. Asia and Africa in modern world politics. Digest of articles. M.: IMEMO RAN, 10.

5. Speech by the President of the Republic of Uzbekistan H.E. Mr. Shavkat Mirziyoyev at the 75th Session of the United Nations General Assembly. 23 September 2020. Available at: https://www.un.int/uzbekistan/news/s peech-president-republic-uzbekistanhe-mr-shavkat-mirziyoyev-75thsession-united-nations (accessed 25.09.2020)

6. Konovalova, N.A. (2018). Russia's foreign policy in the framework of the modern international system. Russia and the modern world. 1 (98), 135.

7. Lavrov, S.V. (2016). Historical perspective of Russian foreign policy. Russia in global politics. No. 2, 8-20.

8. Asian Development Bank. Asian Economic Integration Report - 2017. Available at: https://www.adb.org/sites/default/files /publication/375196/aeir-2017.pdf (accessed 12.09.2020)

9. Mikheev, V.V. (2008). The role of China in the globalizing world. Perspectives. Available at: http://www.perspektivy.info/book/rol_ kitaja_v_

globalizujushhemsa_mire_2008-09-

04.htm (accessed 12.09.2020)

10. Novikov, D.P. (2018). Great Eurasian partnership: possible regional influence and interests of Russia. Bulletin of international organizations. Vol.13. Iss.3, 83.

11. Putin called for the creation of a great Eurasian partnership. 06/17/2016. Available at: https://tass.ru/pmef- 2016/article/3376295

(accessed

12.09.2020)

12. Putin, V. (2017). XXV APEC Summit in Da Nang: Together to Prosperity and Harmonious Development. November 8. Available at: http://kremlin.ru/events/president/ne ws/56023 (accessed 12.09.2020)

13. Li Yonghui. (2018). Great Eurasian Partnership and Sino-Russian Relations. China in World and Regional Politics. History and modernity. 23, 4445.

14. Bordachev, T.V. (2015). New Eurasianism. How to make pairing work? Russia in global politics. Iss. September / October, 194.

15. Cooley, A. (2016). The Emerging Political Economy of OBOR: The Challenges of Promoting Connectivity in Central Asia and Beyond. A report of the CSIS Simon Chair in Political economy. Washington, DC: Center for Strategic and International Studies, 9.

16. Luzyanin, S.G., Klimenko, A.F. (2019). Cooperation between Russia and China in the SCO to implement the concept of the Greater Eurasian Partnership. China in world and regional politics. History and modernity. Vol. 24. Iss.24, 98-113.

17. Idirov, U. (2018). Strengthening of interrelations between globalization, security and democratic development in the contemporary world. Paradigmata poznani. Paradigms of knowledge. No. 4, 46-49.

18. Saydaliyeva, N., Nazirov, M. (2018). Features of the state youth policy in Uzbekistan. Paradigmata poznani. Paradigms of knowledge. No. 4, 117120.

19. Saydaliyeva, N., Nazirov, M. (2020). Youth policy as a priority area of 
Doi: https://doi.org/10.37547/tajpslc/Volume02Issue11-05

development. Sociosphere. No.3, 104-

105.

20. Muhammadsidikov, M. (2015).

Özbekistan'da toplumsal yaşamin ana özelliği hoşgörü. Atatürk Üniversitesi Sosyal Bilimler Dergisi. O (54), 7-14. Available at: https://dergipark.org.tr/en/pub/ataunis osbd/issue/2811/37766 (accessed 12.09.2020)

21. Muhammadsidiqov, M. (2019). Problems of regulation of secularism and religious principles in Arab countries. Bulletin Social-Economic and Humanitarian Research. No. 4(6). Available at: https://cyberleninka.ru/ article/n/problems-of-regulation-ofsecularism-and-religious-principles-inarab-countries (accessed 12.09.2020)

22. Berdiyev, B. (2020). Central Asia: international relations as a factor of regional stability and integration. The American Journal of Political Science Law and Criminology. Vol. 02. Iss.10, 118-122. 